\title{
Lifestyle issues in inflammatory bowel disease - Smoking
}

\author{
CECILIA BENONI MD DrMedSci
}

C BENONI. Lifestyle issues in inflammatory bowel disease - Smoking. Can J Gastroenterol 1994;8(7):422-427. During the past decade, smoking habit has been identified as a major exogenous factor in inflammatory bowel disease (IBD). It is associated not only with the development of the disease but also with the clinical course in established disease. IBD combines absolute opposites as smoking is associated with Crohn's disease and nonsmoking or former smoking with ulcerative colitis. The first reports of a negative association between smoking and ulcerative colitis were based on independent, clinical observations; from those studies a positive association was found between smoking and Crohn's disease. Epidemiological studies that followed consistently showed that smokers have a reduced risk of ulcerative colitis and an increased risk of Crohn's disease and that exsmokers have an increased risk of ulcerative colitis. In ulcerative colitis, but not in Crohn's disease, a dose-response pattern has been demonstrated. Changes in clinical course, in disease severity and extension, and in recurrence rate indicate substantial clinical effects of smoking with a protective effect of smoking in ulcerative colitis and an aggravating effect in Crohn's disease. There are also indications of smoking's effects on changes in IBD epidemiology and sex distribution. The biological explanation to the findings is unknown. Smoking may aggravate Crohn's disease by vascular effects. Theories on the protective effect in ulcerative colitis include effects on immune and inflammatory response, on mucus and on intestinal permeability. Possibly, beneficial effects in ulcerative colitis are exerted by nicotine but further studies are needed. Due to overall negative effects of smoking, IBD patients should not smoke. It seems, however, reasonable to give individual advice in patients with ulcerative colitis who have experienced a beneficial effect of smoking considering both current health status and life situation.

Key Words: Crohn's disease, Inflammatory bowel disease, Lifestyle, Nicotine, Smoking, Ulcerative colitis

\section{Mode de vie et maladies inflammatoires de l'intestin : Tabagisme}

RÉSUMÉ : Au cours de la dernière décennie, le tabagisme a été identifié comme l'un des grands facteurs exogènes de la maladie inflammatoire de l'intestin (MII). On l'associe non seulement au développement de certaines maladies, mais aussi

voir page suivante

Department of Medicine, Helsingborg Hospital, Helsingborg, Sweden

Correspondence and reprints: Dr C Benoni, Department of Medicine, Helsingborg Hospital, S-251 87 Helsingborg, Sweden

This paper was presented at the Trends in Inflammatory Bowel Disease Therapy meeting, April 6 to 9, 1994, held in Victoria, British Columbia. This paper has also been published in Sutherland LR, et al, eds. Inflammatory Bowel Disease: Basic Research, Clinical Implications and Trends in Therapy. Boston, Dordrecht and London: Kluwer Academic Publishers, 1994
$\mathrm{D}$ UE TO THE INCREASING INCIDENCE of inflammatory bowel disease (IBD), particularly the steep increase in Crohn's disease, a number of exogenous factors have been considered in the development of the diseases. These factors could be of importance both in the first attack as well as in recurrence and relapse.

During the past decade, smoking habit has been identified as a strong, perhaps the strongest, exogenous factor in IBD. Paradoxically, the diseases in this context are absolute opposites. A number of studies consistently show that smoking is associated with Crohn's disease, and nonsmoking or former smoking with ulcerative colitis. Smoking habit not only is associated with the first outbreak but also seems to be of substantial importance during the clinical course of the diseases.

\section{EPIDEMIOLOGICAL FINDINGS}

In the early 1980s, independent observations were made on the possible protective effects of smoking in ulcerative colitis (1-4). It was earlier known that patients with ulcerative colitis smoked less than matched controls (5). The author interpreted this as a consequence of the chronic disease.

Findings in a study of effects of smoking on nutritional status in IBD (6) stimulated Harries and co-workers (1) to study smoking habits in patients with ulcerative colitis and Crohn's disease. A low prevalence of smoking (8\%) was found in ulcerative colitis patients. There were equal proportions of nonsmokers and exsmokers. It was 
à l'évolution clinique de maladies existantes. À ce chapitre, ces deux maladies s'opposent diamétralement puisque le tabagisme est associé à la maladie de Crohn et le statut de non-fumeur ou d'ex-fumeur, à la colite ulcéreuse. Les premiers rapports de liens négatifs entre tabagisme et colite ulcéreuse se basent sur des observations cliniques indépendantes. Les études épidémiologiques subséquentes ont toujours montré que les fumeurs sont exposés à un risque réduit de colite ulcéreuse et à un risque accru de maladie de Crohn et que les ex-fumeurs sont exposés à un risque plus grand de colite ulcéreuse. Dans la colite ulcéreuse, contrairement à la maladie de Crohn, un modèle dose-réponse a pu être établi. Les changements affectant l'évolution clinique, la gravité de l'état, l'étendue de l'atteinte et le taux de récurrence témoignent des effets cliniques substantiels du tabagisme, soit un effet protecteur dans la colite ulcéreuse et un effet délétère dans la maladie de Crohn. Certaines observations signalent un lien entre les effets du tabagisme et certaines modifications épidémiologiques concernant les maladies inflammatoires de l'intestin et la distribution selon le sexe. L'explication biologique de ces observations est inconnue. Le tabagisme peut aggraver la maladie de Crohn par le biais de facteurs vasculaires. Les théories sur l'effet protecteur conféré dans la maladie de Crohn mentionnent une action sur la réponse immunitaire et inflammatoire, sur la muqueuse et sur la perméabilité intestinale. Il est possible que les effets bénéfiques observés dans la colite ulcéreuse soient apportés par la nicotine, mais des études devront le confirmer. Compte tenu des effets globalement nocifs du tabagisme, les patients atteints de MII devraient s'abstenir de fumer. Il semble toutefois raisonnable de conseiller individuellement les patients atteints de colite ulcéreuse qui ont semblé tirer un effet bénéfique de leur tabagisme, compte tenu de leur état de santé et de leur situation de vie.

noted that the exsmokers usually had given up smoking before the onset of symptoms. A Czech study by Bures and co-workers (2) described the same association.

A male patient with ulcerative colitis who could not stop smoking due to relapses after stopping initiated a study by the author's group (3); they compared smoking habits in ulcerative colitis and Crohn's disease patients with national figures on smoking. This design was chosen to evaluate possible effects of the disease on smoking habit. These researchers found similar data with a low number of smokers with ulcerative colitis, but could also describe a distinct time relationship between stopping smoking and disease onset. Gyde and colleagues ( 7 ) reported a low number of cardiovascular and pulmonary deaths in male patients with ulcerative colitis. This was followed up by the same authors in a risk factor study (4) and could most probably be attributed to the absence of smoking in ulcerative colitis patients.

The early reports of Harries et al (1) stimulated others to study the relationship between smoking and ulcerative colitis in the Boston Collaborative Drug Surveillance Program (8). They confirmed that smoking was underrepresented in ulcerative colitis patients. A link between heavy smoking and lower risk was also found.

Using community controls, Logan and co-workers (9) showed an increased relative risk of 6.2 in nonsmokers of both sexes when smoking habits were examined at the onset of disease. They subsequently showed that the relative risk of ulcerative colitis in smokers was one-third that of nonsmokers and in exsmokers was threefold increased (10).

The primary interest of smoking in IBD concerned ulcerative colitis only. At the same time, the first studies also pointed to a high number of smokers among Crohn's disease patients. In the study by Harries et al (1), the positive association between smoking and Crohn's disease was not observed, probably due to the fact that the controls were chosen from a group with a higher number of smokers than in the general population. The author's group found that smoking was significantly more common in Crohn's disease than in ul- cerative colitis patients (3), similar to the findings of Holdstock (11). Somerville and co-workers (12), using the same design as in their former study on ulcerative colitis (9), described a significant positive association between smoking and Crohn's disease. The association was stronger for smoking habit before the onset of the disease than for current habits. The relative risk for smokers of both sexes at onset was nearly five times that of nonsmokers. It is worth noting that the risk for women smokers was eight times that of nonsmokers.

A number of epidemiological studies from different countries have been performed. Despite different study designs, the findings have been consistent. Selected studies are included in a metaanalysis by Calkins (13) which confirms that smokers have a reduced risk of ulcerative colitis and an increased risk of Crohn's disease. The analysis also shows an increased risk of ulcerative colitis in exsmokers. A doseresponse pattern is demonstrated in ulcerative colitis with a decreasing risk with increasing current smoking. In exsmokers, the risk increases with increasing former usage. No dose response pattern can be demonstrated in Crohn's disease. The study also critically evaluates the findings against defined criteria for causality.

\section{EFFECTS OF SMOKING HABIT ON CLINICAL COURSE}

Evidence of a causal relationship between smoking habit and IBD would be further strengthened if the habit or the changing of it - interfered with the clinical course of the diseases. Do we have further evidence of a truly beneficial effect of smoking in ulcerative colitis and a harmful effect in Crohn's disease? What is the impact of stopping smoking - and of taking it up again - in newly diagnosed or established ulcerative colitis? Does smoking influence the time of onset, the severity and the extension of the disease?

In Crohn's disease, does smoking make the clinical course worse? Does it influence the distribution and localization of the inflammation? Could such 
an association illuminate the biological explanation behind the findings?

Shortly after the publication by Harries and associates (1), case reports by de Castella (14) and Roberts and Diggle (15) described two women with ulcerative colitis who relapsed shortly after stopping smoking, and these relapses were reproducible. One patient went into remission by resuming smoking, the other by starting chewing nicotine gum. These reports arouse suspicions about the possible clinical role of stopping smoking in established ulcerative colitis and the role of nicotine as the responsible protective agent.

Studies by Benoni and Nilsson (3, 16) focused on the possible temporal relationship between smoking cessation and disease onset in ulcerative colitis patients. Such a relation would indicate a beneficial effect of smoking. Among exsmokers, the majority had a first attack within four years of stopping. Exsmoking was more common in men, and disease onset after stopping smoking occurred in all age groups. There was a male dominance among older patients who fell ill. A similar time relationship was later demonstrated by Motley and co-workers (17). Rudra et al (18) interviewed exsmokers who had taken up smoking again and found that half of them felt improvement after restarting. Motley et al also described how the presence of a smoking history in men delayed the onset of ulcerative colitis for a mean of 15 years compared with never smokers. There was no such pattern in women (17).

There was no temporal relationship between smoking cessation and onset in Crohn's disease patients (3).

Colectomy and hospitalization rate due to disease relapse are parameters of disease severity. Boyko and co-workers (19) studied the effects of smoking habit on clinical course by comparing disease activity in smokers and nonsmokers measured by yearly number of hospitalizations and the need for a colectomy. They found that both hospitalization and colectomy occurred more frequently in patients who had stopped smoking before disease onset compared with smokers and never smokers. They also found that smokers were hospitalized less often than nonsmokers but colectomy rate was the same.

Irrespective of indication, the author's group (3) did not find any relation between colectomy rate and smoking habit, but noted that the exsmokers were older at the time of operation.

If smoking is protective in ulcerative colitis, it seems likely that it protects against more extensive disease. When smoking habit and extension at the time of the diagnosis is considered, no correlation is found $(9,16,17,20,21)$. If, instead, disease extension at the time of the interview is considered, this more adequately reflects a protective effect of smoking. This has been done in a study by Samuelsson and associates (22) who showed that patients with extensive inflammation more seldom had a smoking history compared with those who had nonprogressive proctitis. This suggests a protective effect of smoking against disease extension.

If smoking is beneficial in ulcerative colitis, what evidence do we have of a harmful effect in Crohn's disease? It should be taken into consideration that the negative association between smoking and ulcerative colitis is likely to be a stronger finding than the positive association between smoking and Crohn's disease. Smoking in Crohn's disease may be associated with other lifestyle factors and those may, either by themselves or in combination with smoking, aggravate the inflammation. The use of oral contraceptives is an example of a possible interactive risk factor in Crohn's disease (23).

The effects of smoking on the clinical course in Crohn's disease have been addressed in some studies. Expressed as the frequency of relapses and the intensity of symptoms it was demonstrated by Holdstock and co-workers (11) that smokers tended to have a more severe course compared with nonsmokers. Sutherland et al (24) found that the recurrence rate, defined as the need for further surgery, was higher in smokers compared with nonsmokers. This increased risk was found to be more apparent in women than in men, once again indicating sex differences. The authors also found evidence of a dose response relationship in women which was not found in men. Lindberg and co-workers (25) confirm the association between heavy smoking and an increased risk of a second resection.

The findings of opposite smoking habits in Crohn's disease and ulcerative colitis raise the possibility that smoking may be associated with the localization of the inflammation. Is nonsmoking associated with isolated colonic disease and smoking with small bowel disease? There are data indicating this.

Holdstock and colleagues (11) found that patients with Crohn's colitis smoked less than those with small bowel disease. Others also reported that small bowel disease was more frequent than isolated colonic or combined small and large bowel disease in patients who were heavy smokers (25). Thus, there seems to be an association in Crohn's disease, not only between heavy smoking and disease severity, but also between heavy smoking and small bowel disease. Whether smoking is protective to colonic disease in Crohn's disease as it is in ulcerative colitis should be evaluated further.

\section{SMOKING AND TRENDS IN EPIDEMIOLOGY}

Effects of smoking in IBD may be seen also in a wider perspective. Smoking habits have changed during the past decades. Men have stopped smoking while women have started. These changes may have influenced the epidemiology in IBD; there seems to be some evidence for this. Ulcerative colitis affects both sexes almost equally. Some studies, however, describe an increase in ulcerative colitis incidence since the 1970s in middle-aged and older men $(26,27)$. Perhaps changing smoking habits in men should be considered as a factor in this epidemiology.

Further evidence of such effects can be found in a review by Tysk and Järnerot (28) who plotted the male: female ratios in ulcerative colitis in 60 years of epidemiological studies. They found a change in sex distribution during these years so that ulcerative colitis, which once was a disease with a female dominance, now seems to have turned to a disease with a male dominance. 
The increased risk of Crohn's disease in smokers is associated with female sex (13). Studies of IBD incidence during the past and present decades will answer the question whether the influence of smoking habit in IBD is strong enough to induce changes in the epidemiology.

\section{BIOLOGICAL ROLE OF SMOKING IN IBD}

What is the biological role of smoking in IBD and by what mechanisms does smoking exert its effects? As we do not know the pathogenesis of IBD, discussions on the biological effects of smoking remain hypothetical.

It has been proposed that Crohn's disease is a multifocal gastrointestinal infarction on the basis of a chronic mesenteric vasculitis (29). As smoking has potent vascular injurious effects inducing a tendency for focal thrombosis, negative effects of smoking in Crohn's disease might well be explained by this (23). Smoking in this context also may interact with other potentially diseaseprovoking factors in Crohn's disease, eg, oral contraceptives (23).

Smoking has a number of known effects on immune and inflammatory functions, some of which might explain a protective effect in ulcerative colitis. These studies have been done on alveolar cells and on blood cells and the changes may not be relevant for local immune events in the gut. Effects on salivary immunoglobulins (Ig) may, however, reflect general effects of smoking on mucosal immune functions.

Smoking influences both cell-mediated and humoral immunity. Light to moderate smoking increases the $\mathrm{T}$ helper-inducer population while heavy smoking increases the $T$ suppressor cell population (30).

Smoking also lowers the circulating levels of serum $\operatorname{IgG}, \mathrm{A}$ and $\mathrm{M}(31)$ as well as the level of salivary $\operatorname{IgA}$, which represents a mucosal immune response (32). These effects are reversible. In addition, smoking interferes with macrophage functions as studied on alveolar macrophages obtained from bronchoalveolar lavage fluid. Smoking inhibits the release of leukotriene B4
(LTB4), thus reducing the cells' chemotactic abilities (33). It also decreases the production of interleukin-1 from these cells (34). In addition, smoking influences the function of circulating neutrophil leukocytes (35). Extrinsic alveolitis as well as sarcoidosis are diseases that are underrepresented in smokers possibly due to the effects of smoking on antigen presentation (34). These effects of smoking may be representative also for immune and inflammatory response in the gut mucosa in ulcerative colitis.

Srivastava and co-workers (36) have examined levels of immunoglobulin titres in gut lavage in smoking and nonsmoking patients with ulcerative colitis and controls. They found significantly reduced levels of $\operatorname{IgA}$ in lavage from smoking patients compared with controls but no other differences. The smoking patients, however, had a low cigarette consumption and it is possible that more substantial effects would have been seen with heavier smokers. Motley and his group (37) examined the immeditate effects of smoking on the production of arachidonic acid metabolites in colonic mucosa; there was a tendency, though not significant, for smokers to have a lower production. Srivastava and co-workers (38) proposed that smoking may protect by lowering the rectal bloodflow in ulcerative colitis patients.

In addition, the author's groups have compared smoking habits in ulcerative colitis with 'model diseases' $(39,40)$. Systemic lupus erythematosus is a disorder with an accepted autoimmune pathogenesis. In rheumatoid arthritis a main event is a local infiltration of leukocytes in the synovia. Effects of smoking on immune and inflammatory function might be noticeable in the clinical course of these diseases; however, no such relationship has been found.

Another rationale for a protective effect of smoking in ulcerative colitis may be that smoking influences intestinal permeability and thus the uptake of potentially disease provoking substances. This could be induced in different modes. The compositions of colonic mucus in smoking and non- smoking patients with ulcerative colitis differed significantly in a study by Cope and co-workers (41). Smokers were found to have a mucus production similar to controls.

Principally, water soluble substances in the gut can take two routes through the intestinal mucosa. It is proposed that PEG400 passes transcellularly and that ${ }^{51}$ CrEDTA passes paracellularly through the tight junctions (42) When given orally, both substances are taken up along the small bowel. In contrast, there is a significant uptake of ${ }^{51}$ CrEDTA but not of PEG400 in the colon (42). The author's group (43) has studied the effects of smoking on the urine excretion of ${ }^{51}$ CrEDTA and PEG400 after an oral load; they found no differences in the $6 \mathrm{~h}$ urine excretions of PEG400 between healthy smokers and never smokers. The $24 \mathrm{~h}$ urine excretion of ${ }^{51}$ CrEDTA, however, was significantly lower in smokers compared with never smokers. These findings support an effect of smoking on the paracellular pathway or an effect on colonic uptake. In an ongoing study of patients with well-defined ulcerative colitis in remission there was a similar difference (40).

\section{NICOTINE - THE PHARMACOLOGICALLY RESPONSIBLE AGENT?}

There are thousands of substances in tobacco. Which of these is responsible for the beneficial effect of smoking in ulcerative colitis? The role of nicotine was suggested early (15) and was introduced in clinical trials. Studies on limited unselected patient groups using nicotine chewing gum have, however, not shown any convincing effects (44) In a recent study by Pullan and colleagues (45) transdermal nicotine was added to the treatment in active ulcerative colitis. This study showed favourable effects both on symptoms and endoscopic and histological findings but requires confirmation in further trials.

So far, there are indications that nicotine might be pharmacologically responsible for the biological effects of smoking in ulcerative colitis. However, we are still left with crucial questions. Who will benefit from nicotine treat- 
ment and when should it be started? Does it really have any advantages over traditional medical treatment in ulcerative colitis?

\section{CONCLUSIONS AND CONSEQUENCES}

A number of studies consistently show that smoking has profound effects in IBD both before disease onset and during its course. It is easier to understand biologically why smoking is harmful in Crohn's disease than beneficial in ulcerative colitis. Possibly, this beneficial effect of smoking is exerted by nicotine but further studies evaluat-

\section{REFERENCES}

1. Harries AD, Baird A, Rhodes J. Non-smoking: a feature of ulcerative colitis. Br Med J 1982;284:706.

2. Bures J, Fixs B, Komarkova O, Fingerland A. Non-smoking: A feature of ulcerative colitis. Br Med J 1982;285:440. (Lett)

3. Benoni C, Nilsson A. Smoking habits in patients with inflammatory bowel disease. Scand J Gastroenterol 1984;19:824-30.

4. Gyde SN, Prior P, Alexander F, et al. Ulcerative colitis: Why is the mortality from cardiovascular disease reduced? Q J Med 1984;211:351-7.

5. Samuelsson SM. Ulcerös colit och proctit. Uppsala: Department of social medicine: University of Uppsala, 1976. (Thesis)

6. Harries AD, Jones L, Heatley RV, Rhodes J. Smoking habits and inflammatory bowel disease: effect on nutrition. Br Med J 1982;284:1161.

7. Gyde S, Prior P, Dew MJ, Saunders V, Waterhouse JAH, Allan RN. Mortality in ulcerative colitis. Gastroenterology 1982;83:36-43.

8. Jick H, Walker AM. Cigarette smoking and ulcerative colitis. N Engl J Med 1983;308:261-3.

9. Logan RFA, Edmond M, Somerville KW, Langman MJS. Smoking and ulcerative colitis. Br Med J 1984;288:751-3.

10. Logan R, Langman MJS. Smoking and ulcerative colitis. Br Med J 1984;288:1307. (Lett)

11. Holdstock G, Savage D, Harman M, Wright R. Should patients with inflammatory bowel disease smoke? Br Med J 1984;288:362.

12. Somerville KW, Logan RFA, Edmond M, Langman MJS. Smoking and Crohn's disease. Br Med J 1984;289:954-6.

13. Calkins BM. A metaanalysis of the role of smoking in inflammatory bowel ing the role of nicotine in established disease are awaited.

Recent studies have described how passive smoking in childhood may be associated with IBD $(46,47)$. It is of utmost importance to evaluate these findings as they concern the information and advice we give to our patients, as well as to their healthy relatives.

The most important consequence of the findings of an association between smoking and IBD concerns the advice given. Patients with IBD are very well informed and aware of lifestyle factors. Due to overall negative effects of smok-

disease. Dig Dis Sci 1989;34:1841-54.

14. De Castella $\mathrm{H}$. Non smoking: a feature of ulcerative colitis. Br Med J 1982;284:1706. (Lett)

15. Roberts CJ, Diggle R. Non smoking: a feature of ulcerative colitis. Br Med J 1982;285:440. (Lett)

16. Benoni $\mathrm{C}, \mathrm{Nilsson} \AA$. Smoking habits in patients with inflammatory bowel disease. A case-control study. Scand J Gastroenterol 1987;22:1130-6.

17. Motley RJ, Rhodes J, Kay S, Morris TJ. Late presentation of ulcerative colitis in ex-smokers. Int J Colorect Dis 1988;3:171-5.

18. Rudra T, Motley R, Rhodes J. Does smoking improve colitis? Scand J Gastroenterol 1989;170(Suppl):61-3.

19. Boyko EJ, Perera DR, Koepsell TD, Keane EM, Inui TS. Effects of cigarette smoking on the clinical course of ulcerative colitis. Scand J

Gastroenterol 1988;23:1147-52.

20. Tobin MV, Logan RFA, Langman MJS, McConnell RB, Gilmore IT. Cigarette smoking and inflammatory bowel disease. Gastroenterology 1987;93:316-21.

21. Srivastava ED, Newcombe RG, Rhodes J, Avramidis P, Mayberry JF. Smoking and ulcerative colitis: a community study. Int J Colorect Dis 1993;8:71-4.

22. Samuelsson SM, Ekbom A, Zack M, Helmick CG, Adami HO. Risk factors for extensive ulcerative colitis and ulcerative proctitis: a population based case-control study. Gut 1991;32:1526-30.

23. Wakefield AJ, Sawyerr AM, Hudson M, Dhillon AP, Pounder RE. Smoking, the oral contraceptive pill, and Crohn's disease. Dig Dis Sci 1991;36:1147-50.

24. Sutherland LR, Ramcharan S, Bryant H, Fick G. Effect of cigarette smoking on recurrence of Crohn's disease. Gastroenterology 1990;98:1123-8. ing, the general rule must be that patients with IBD should be nonsmokers. Smokers with Crohn's disease should be offered help to stop. It would, however, seem reasonable to give individual advice to smoking patients with ulcerative colitis as to when and how they should stop smoking, taking into consideration both existing health status as well as existing life situation. In addition, selected exsmokers with ulcerative colitis should be offered the possibility to try nicotine treatment instead of resuming smoking if there is a positive history of smoking on their clinical course.

25. Lindberg E, Järnerot G, Huitfeldt B. Smoking in Crohn's disease: effect on localisation and clinical course. Gut 1992;33:779-82.

26. Nordenvall B, Broström O, Berglund $\mathrm{M}$, et al. Incidence of ulcerative colitis in Stockholm County 1955-1979. Scand J Gastroenterol 1985;20:783-90.

27. Binder V, Both H, Hansen PK, Hendriksen C, Kreiner S, TorpPedersen K. Incidence and prevalence of ulcerative colitis and Crohn's disease in the County of Copenhagen, 1962-1978. Gastroenterology 1982;83:563-8.

28. Tysk C, Järnerot G. Has smoking changed the epidemiology of ulcerative colitis? Scand J Gastroenterol 1992;27:508-12.

29. Wakefield AJ, Sawyerr AM, Dhillon AP, et al. Pathogenesis of Crohn's disease: multifocal gastrointestinal infarction. Lancet 1989;ii:1057-62.

30. Miller LG, Goldstein G, Murphy M, Ginns LC. Reversible alterations in immunoregulatory $\mathrm{T}$ cells in smoking. Analysis by monoclonal antibodies and flow cytometry. Chest 1982;82:526-9.

31. Gerrard JW, Heiner DC, Ko CG, Mink J, Meyers A, Dosman JA. Immunoglobulin levels in smokers and nonsmokers. Ann Allergy 1980;44:261-2.

32. Barton JR, Riad MA, Gaze MN, Maran AGD, Ferguson A. Mucosal immunodeficiency in smokers, and in patients with epithelial head and neck tumours. Gut 1990;31:378-82.

33. Tardif J, Borgeat P, Laviolette $\mathrm{M}$. Inhibition of human alveolar macrophage production of leukotriene B4 by acute in vitro and in vivo exposure to tobacco smoke. Am J Respir Cell Mol Biol 1990;2:155-61.

34. Yamaguchi E, Okazaki N, Itoh A, Abe S, Kawakami Y, Okuyama H. Interleukin-1 production by alveolar 
macrophages is decreased in smokers. Am Rev Respir Dis 1989;140:397-402.

35. Noble RC, Penny BB. Comparison of leukocyte count and function in smoking and non-smoking young men. Infect Immun 1975;12:550-5.

36. Srivastava ED, Barton JR, O'Mahony $\mathrm{S}$, et al. Smoking, humoral immunity and ulcerative colitis. Gut 1991;32:1016-9.

37. Motley RJ, Rhodes J, Williams G, Tavares IA, Bennet A. Smoking, eicosanoids and ulcerative colitis. J Pharm Pharmacol 1990;42:288-9.

38. Srivastava ED, Russell MAH, Feyerabend C, Rhodes J. Effect of ulcerative colitis and smoking on rectal blood flow. Gut 1990;31:1021-4. 39. Benoni C, Nilsson A. Smoking and inflammatory bowel disease: Comparison with systemic lupus erythematosus. A case-control study. Scand J Gastroenterol 1990;25:751-5.

40. Benoni C. Inflammatory bowel disease. Studies on the role of smoking. Doctoral dissertation, Lund University, 1991.

41. Cope GF, Heatley RV, Kelleher J. Smoking and colonic mucus in ulcerative colitis. Br Med J 1986;293:481.

42. Travis S, Menzies I. Intestinal permeability: functional assessment and significance. Clin Sci 1992;82:471-88.

43. Prytz H, Benoni C, Tagesson C. Does smoking tighten the gut? Scand J Gastroenterol 1989;24:1084-8.
44. Lashner BA, Hanauer SB, Silverstein MD. Testing nicotine gum for ulcerative colitis patients. Experience with single-patient trials. Dig Dis Sci 1990;35:827-32.

45. Pullan RD, Rhodes J, Ganesh S, et al. Transdermal nicotine for active ulcerative colitis. N Engl J Med 1994;330:811-5.

46. Persson P-G, Ahlbom A, Hellers G. Inflammatory bowel disease and tobacco smoke - a case-control study. Gut 1990;31:1377-81.

47. Sandler RS, Sandler DP, McDonnell CW, Wurzelmann JI. Childhood exposure to environmental tobacco smoke and the risk of ulcerative colitis. Am J Epidemiol 1992;135:603-8. 


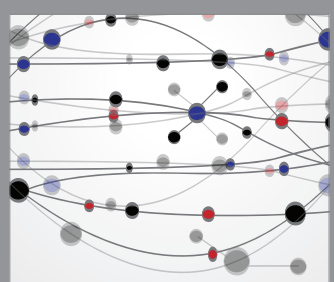

The Scientific World Journal
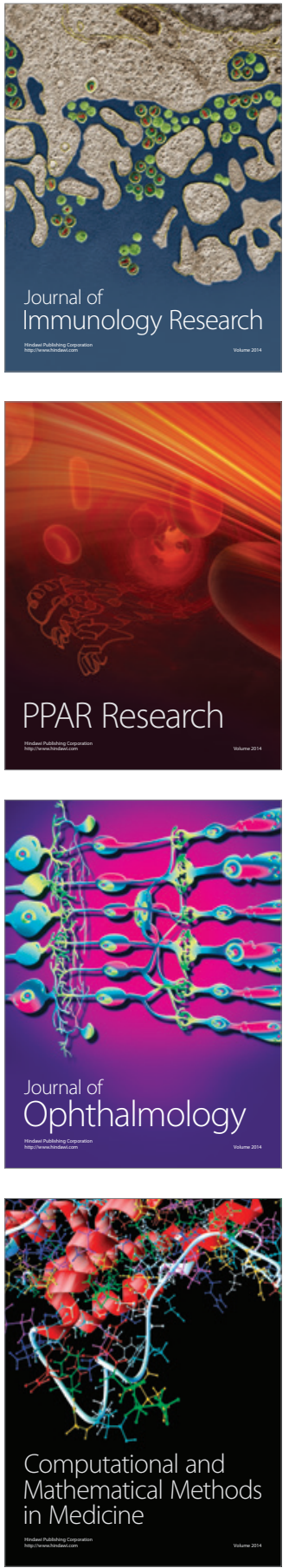

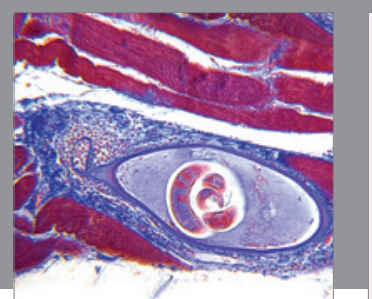

Gastroenterology Research and Practice

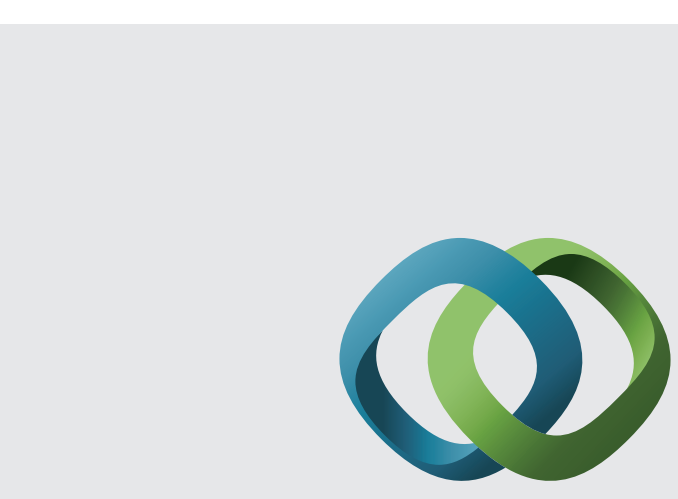

\section{Hindawi}

Submit your manuscripts at

http://www.hindawi.com
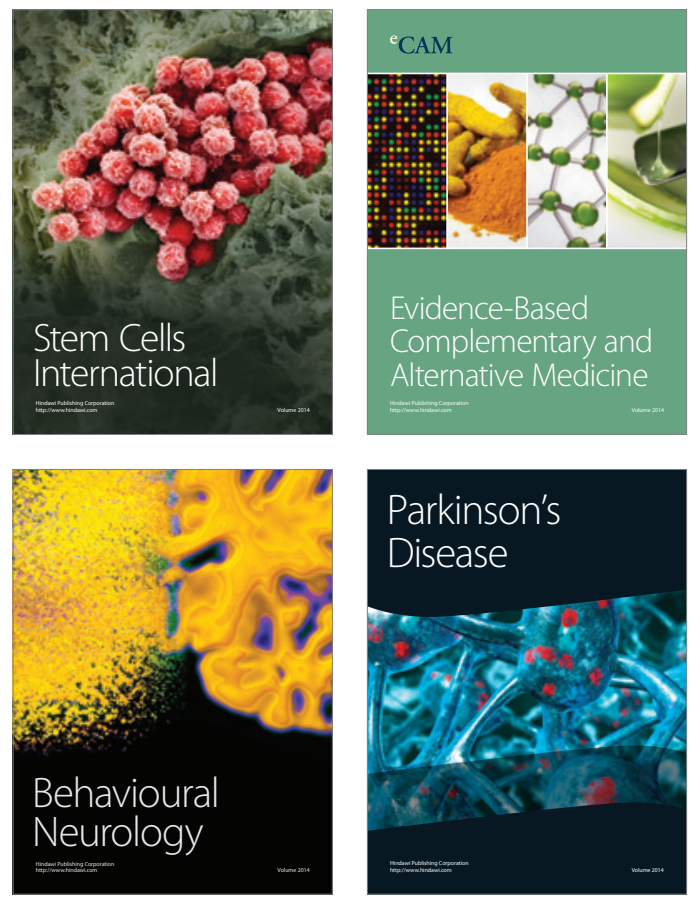
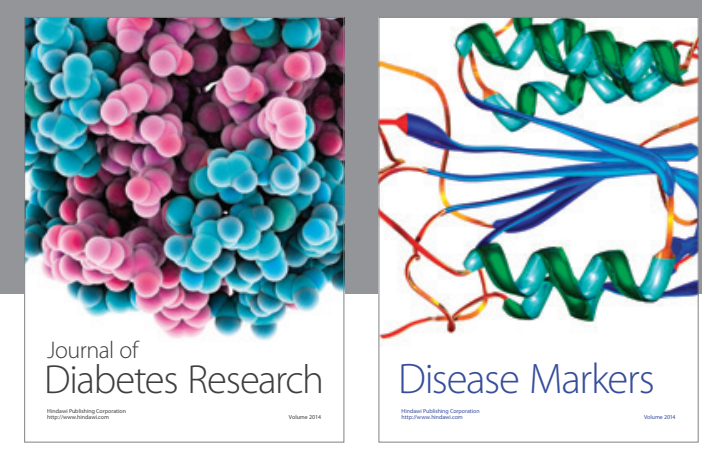

Disease Markers
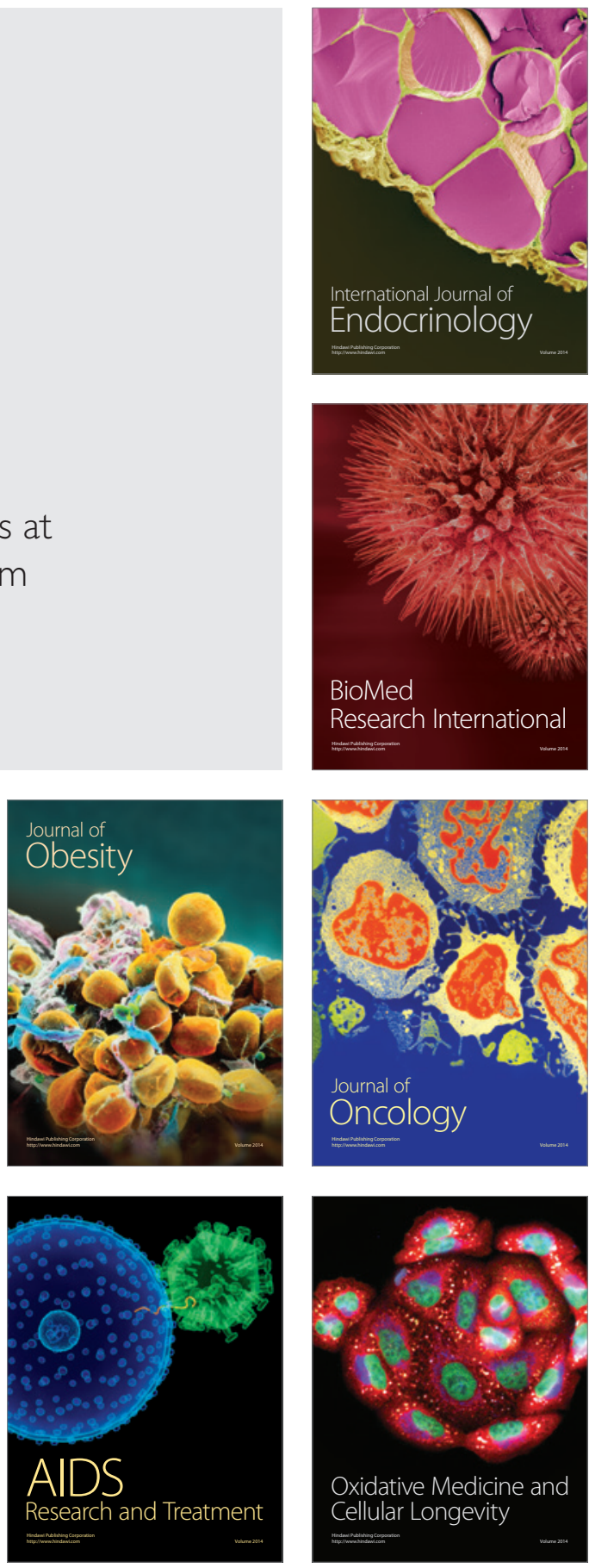